\title{
Fat absorption after total gastrectomy in rats submitted to Roux-en-Y or Rosanov-like double-transit technique ${ }^{1}$
}

\author{
Absorção de gordura após gastrectomia total em ratos com reconstrução em Y de \\ Roux e em duplo trânsito tipo Rosanov modificado
}

\author{
Gustavo Sevá-Pereira ${ }^{2}$, Luiz Roberto Lopes ${ }^{3}$, Nelson Ary Brandalise ${ }^{4}$, Nelson Adami Andreollo ${ }^{4}$ \\ 1. Research performed at Postgraduate Program in Surgery, School of Medical Science (FCM) of the State University of Campinas \\ (UNICAMP). São Paulo, Brazil. \\ 2. Fellow Master degree, Postgraduate Program in Surgery, FCM - UNICAMP. São Paulo, Brazil. \\ 3. Assistant Professor, Department of Surgery, FCM - UNICAMP. São Paulo, Brazil. \\ 4. Associate Professor, Department of Surgery, FCM - UNICAMP. São Paulo, Brazil.
}

\begin{abstract}
Purpose: Steatorrhea is one of the most common complications in reconstruction after total gastrectomy. Many reconstruction techniques after total gastrectomy have been developed in order to avoid these undesirable effects, but each one of them has some inconvenience. In this experiment, a modified Rosanov technique that keeps duodenal transit, evaluation of fat absorption after gastrectomy was tested. Methods: Three groups of rats with the same characteristics were used. Total gastrectomy was performed in two groups: one was operated on and transit was reestablished by the Roux-en-Y technique (group Y), while the other was submitted to the modified Rosanov technique (group R). Following surgery, a handmade hyper fatty diet (11\% of fat) was offered. A third group (control - group C) was not operated but was submitted to the same conditions of the other groups, and used for reference steatocrit values. The animals underwent laparotomy 14 days after surgery and had their feces collected from cecum to determine their steatocrit by analysis of their values. Results: Steatocrit values for groups R and C (mean 5.16\% and 4.15\% respectively) were similar ( $p>0.1$ ), while group Y had significantly higher values (mean $=28.18 \%, p=0.0001-p<0,05)$. This was attributed to the fact that group $\mathrm{R}$ animals had their duodenal transit patent, decreasing the complications expected in the Roux-en-Y reconstruction. Conclusions: Steatorrhea in the modified Rosanov technique was similar to the control group, while Roux-en-Y reconstruction presented higher steatorrhea and fat malabsorption.
\end{abstract}

Key words: Gastrectomy. Postgastrectomy Syndromes. Anastomosis, Roux-en-Y. Steatorrhea. Diarrhea.

\section{RESUMO}

Objetivo: Uma das principais complicações tardias da gastrectomia total com reconstrução de trânsito excluindo duodeno é a esteatorréia. Várias técnicas de reconstrução após gastrectomia total foram descritas para que se pudesse evitar esses efeitos indesejáveis, mas cada uma apresentou seus inconvenientes. Nesse estudo foi avaliada a técnica descrita por Rosanov com uma pequena modificação, que mantém o trânsito através do duodeno, para avaliar a absorção de gorduras. Métodos: Foram utilizados três grupos de ratos Wistar machos, com peso e características semelhante. Dois grupos foram submetidos à gastrectomia total: o primeiro teve sua reconstrução com técnica de Y de Roux (grupo Y), e o segundo com Rosanov modificado (grupo R). Após a cirurgia, foi introduzida dieta com teor de gorduras conhecido (11\%). Um terceiro grupo (grupo C) esteve sob mesmas condições dos outros animais, sem ter sido submetido à cirurgia, e foi utilizado como grupo controle para o esteatócrito. Após 14 dias, antes de serem sacrificados, foram submetidos a laparotomia para coleta de fezes do ceco e dosagem de esteatócrito. Os valores de esteatócrito foram analisados estatisticamente pelo método de Kruskal-Wallis. Resultados: O esteatócrito dos grupos R (média $=5,16 \%)$ e C (média $=4,15 \%)$ foram semelhantes $(p>0,1)$, enquanto o grupo $Y$ teve valores significativamente maiores (média $=28,18 \%, p-=0.0001-p<0,05$ ). Conclusão: A gastrectomia total com reconstrução tipo Rosanov modificada mostrou esteatorréia semelhante ao grupo controle, enquanto a reconstrução tipo Y de Roux apresentou esteatorréia mais elevada, e portanto malabsorção de gordura.

Descritores: Gastrectomia. Síndromes Pós-Gastrectomia. Anastomose em Y de Roux. Esteatorréia. Diarréia.

\section{Introduction}

Even with bowel transit reconstruction after total or partial gastrectomy, malabsorption still constitutes a great jeopardy in the post-operative period and in many patients is responsible for incapacitating sequelae ${ }^{1,7}$. Diarrhea is a symptom that affects up to $4 \%$ of gastrectomized patients without vagotomy, reaching $8 \%$ when proximal vagotomy is present and $37 \%$ with troncular vagotomy ${ }^{12}$. Many are the etiologies of these symptoms: bowel malabsorption, deconjugated biliary salts passing to the colon, lactase deficiency, dumping syndrome, and steatorrhea ${ }^{4,35}$. To avoid 
the gastrectomy, many technical alternatives have appeared in the history of gastric surgery. Nowadays, the routine of transit reconstruction after total gastrectomy is still the Roux-en-Y technique, because of technical simplicity and low risk of duodenal stump fistulas ${ }^{24}$. The Rosanov technique is similar to Roux-en-Y, but instead of closing the duodenal stump with suture, a lateral-terminal anastomosis between jejunum and duodenum is made with ligation of the it was expected that malabsorption, diarrhea and steatorrhea would be minimized after total gastrectomy. However, little has been reported about this technical alternative, first published in $1958^{17}$. Because the Rosanov technique is one of the few described in which all the alimentary bolus passes through the remaining digestive tract, without duodenal exclusion, without the need to prepare a reservoir and without esophageal-duodenal anastomosis, we believe that this type of reconstruction is a modality in which there should be better nutritional postoperative results. The only modification made in the originally described technique is the absence of external ligature of the jejunal loop (Figure 1). There is no clinical or experimental study in the literature that specifically compares the fat absorption in the two types of intestinal transit reconstruction, Roux-en-Y and Rosanov. Our goals were to evaluate, in rats, postoperative steatorrhea after total gastrectomy, comparing Roux-en-Y and modified Rosanov techniques.

\section{Methods}

Thirty-six male Wistar rats, weights ranging from 260 to $320 \mathrm{~g}$, were supplied by Unicamp, Campinas - SP - Brazil. They were randomly divided into 3 groups: group Y, with 11 animals submitted to total gastrectomy and Roux-en-Y reconstruction; group $\mathrm{R}$, with 13 animals submitted to total gastrectomy and modified Rosanov reconstruction; and group C, called control group, with 12 animals not submitted to surgery. The Figure 1 show the techniques of intestinal reconstruction after total gastrectomy. All animals received the same diet in the preoperative period and fasted the night before surgery. After surgery, they received water on a freedemand basis and the following day they received a diet specifically prepared, with a known fat rate of $11 \%{ }^{35}$. On the $14^{\text {th }}$ day after surgery, all animals were submitted to laparotomy for cecal feces collection, in order to perform the dosage of fecal fat. All of the animals were sacrificed after the procedure. The same procedure was adopted for the group $\mathrm{C}$ animals, 14 days after the beginning of administration of the prepared diet. To evaluate fat absorption, the method of fecal dosage of acid steatocrit was used ${ }^{37}$. The methodology used was descriptive analysis, through positions and dispersion measures. To verify homogeneity and compare the groups, Kruskal-Wallis test was used, with 5\% significance level.

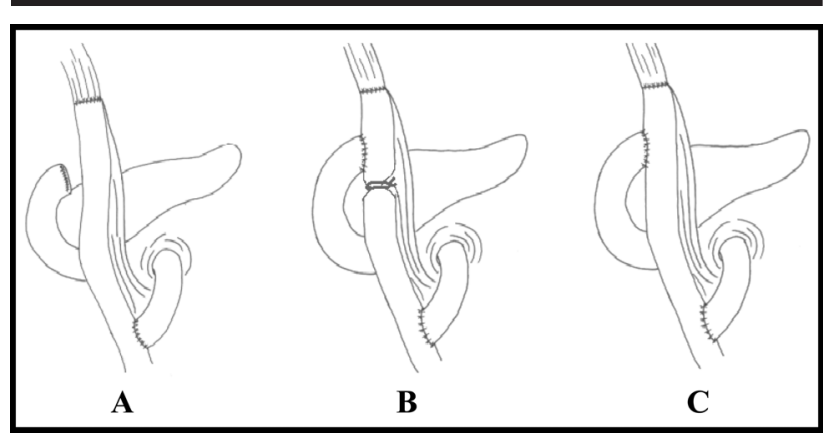

FIGURE 1 - Techniques of intestinal reconstruction after total gastrectomy. A: Roux-en-Y B: Rosanov C: Modified Rosanov

\section{Results}

There was one death on the first post-operative day in group Y, therefore the results were presented with 10 animals. Positions and dispersion steatocrit measures for each group are shown in Table 1. The animals in group $\mathrm{C}$ presented fecal fat percentage from 0 to $16.67 \%$ (mean $4.15 \%$ ). The number of animals showing 0 values was 8 , or $66.67 \%$ of the total. Group Y values were higher, varying from 11.11 to $68.62 \%$, mean $28.18 \%$. In this group no value was below $10 \%$. The animals in group $\mathrm{R}$ presented intermediate values, from 0 to $13.33 \%$, mean $5.16 \%$, close to group C. Four animals showed steatocrit values of 0 . The Figure 2 clearly shows steatocrit values dispersion amongst the groups and the great distance between steatocrit values for the $\mathrm{Y}$ and $\mathrm{R}$ groups, as well as that groups $\mathrm{Y}$ and $\mathrm{R}$, and groups $\mathrm{Y}$ and $\mathrm{C}$ were different between them $(p=0.0001-p<0,05)$.

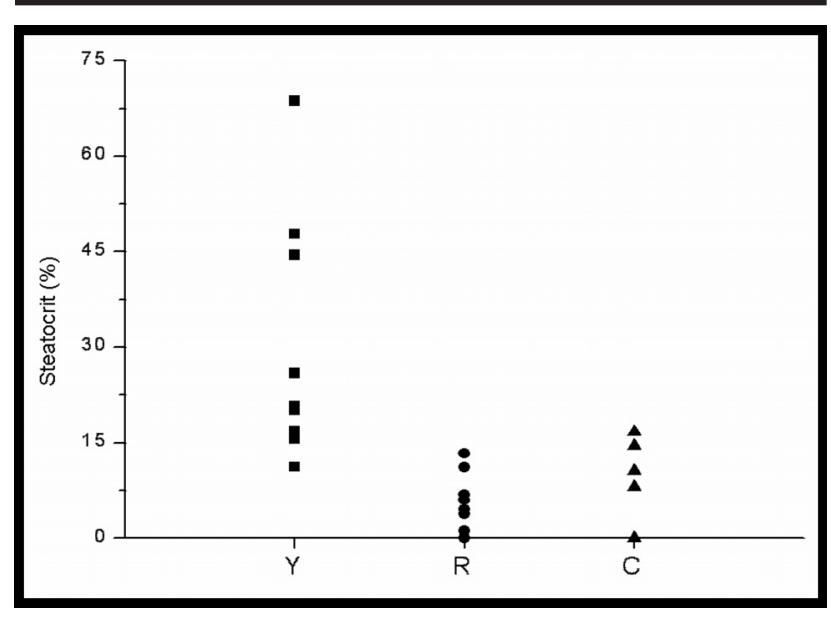

FIGURE 2 - Dispersion of steatocrit measures in each group.

TABLE 1 - Measures of position and dispersion for steatocrit in each group

\begin{tabular}{lcccccc}
\hline Group & N & Mean & $\begin{array}{c}\text { Standard } \\
\text { deviation }\end{array}$ & Mean & Minimum & Maximum \\
\hline GROUPC & 12 & 4.1484 & 6.4559 & 0 & 0 & 16.667 \\
GROUPR & 13 & 4.4647 & 4.3527 & 4.545 & 0 & 13.333 \\
GROUPY & 10 & 28.1777 & 19.1032 & 20.357 & 11.111 & 68.615 \\
\hline
\end{tabular}


Groups $\mathrm{R}$ and $\mathrm{C}$ have similar steatocrit values $(\mathrm{p}>0.1$ $-p>0,05)$. The difference of steatocrit values between the groups $\mathrm{Y}$ and $\mathrm{R}$ (significantly less for group $\mathrm{R}$ ) and the similarity between groups $\mathrm{R}$ and $\mathrm{C}$ show a higher fecal fat loss in group $\mathrm{Y}$ and therefore fat malaborption.

\section{Discussion}

Steatorrhea following total gastrectomy can occur in up to $100 \%$ patients, though the intensity may change $e^{3,6,23,35,36}$. The etiopathogeny of this kind of steatorrhea depends on many combination possibilities of technical resection and transit reconstruction that change the anatomy and physiology of the digestive tract. In this sense, many are the etiological factors that add up $\mathrm{up}^{1,4,9,10,22,23,24,26,38}$ and may lead to variable degrees of steatorrhea ${ }^{19,27}$.

1. Intestinal bacterial overgrowth. Under normal conditions, there is a small number of bacteria in the small bowel. This quantity of bacteria is controlled by some mechanisms, among which are gastric acids and normal bowel peristalsis. When a gastrectomy is performed, the production of acid is at least diminished, and the anastomosis is made beyond the duodenum. When the duodenum is excluded from intestinal transit, there is a bowel loop in which there is no transit of alimentary bolus. If gastric acid, together with alimentary bolus, does not pass inside the duodenum, important controlling mechanisms to avoid bacterial overgrowth are lost. Bacterial overgrowth is one of the main causes of steatorrhea in patients submitted to gastrectomy $y^{1,6,12,20,33,38}$. Therefore, there is a very strong tendency for the bacterial population in the small bowel to multiply, leading to biliary salts deconjugation and rendering them unable to make fat soluble, leading, therefore, to malabsorption and steatorrhea ${ }^{35}$.

2. A rapid intestinal transit time, because of the loss of gastric reservoir and pylorus;

3. Ineffective food and enzymes mixture. A very import effect of duodenal exclusion from alimentary transit is the inability to effectively mix food and biliary secretions, avoiding the initial phase of fat digestion, leading to steatorrhea ${ }^{2}$;

4. Inadequate neuro-hormonal stimulus to the pancreas. When the duodenum is excluded from intestinal transit, there are no stimuli for pancreatic secretions, that can lead to lower production of exocrine pancreatic enzymes, making nutrient absorption more difficult ${ }^{18}$;

5. Smaller absorptive surface, as a result of excluded segment of small bowel. Another factor described as cause of malabsorption is mucosal atrophy, although it is probably among the less important ones ${ }^{10,31}$. From 1930 on, several techniques for intestinal tract reconstruction were described and popularly adopted about 20 years later. After each described technique came the clinical trials comparing this technique to already existing ones and showing its complications and advantages. In the 1970's it was clearly verified that independent of the method, fecal fat loss and malabsorption of proteins were higher in reconstruction techniques that excluded duodenal transit, including Rouxen- $\mathrm{Y}^{6,28,38}$. Further research and new discoveries took place in the field of fat absorption physiopathology. Among the most important are: presence of deconjugated biliary salts and bacterial overgrowth in all patients submitted to gastrectomy, showing that the excluded bowel loop is of major importance in the genesis of post-gastrectomy steatorrhea. Some authors were strongly committed to fighting the idea that Roux-en-Y should be the preferred surgical reconstruction after total gastrectomy ${ }^{6}$. Since then, it became clear that any type of intestinal reconstruction following gastrectomy that would exclude the duodenum would be steatorrhea-productive.

One study conducted by Garofalo and Santoro ${ }^{15}$, including anthropometrical, nutritional, clinical and radiological data, showed that duodenal and jejunal two-way intestinal transit reconstruction after gastrectomy and verified by an Xray study, together with normal fecal fat are two important factors for better quality of life in post-gastrectomy patients. They also found absence of dumping syndrome or weight loss, absence of esophagitis on endoscopy, absence of anemia and electrolyte deficit in patients reconstructed by duodenal transit-preserving technique. Clinical trials in which biochemical and nutritional status of patients submitted to gastrectomy and duodenum-exclusion reconstruction were analyzed after a minimum follow-up of 15 years, showed steatorrhea as an important finding, varying from 14 to $20 \%$, measured by standard tests (Sudam III and fecal fat loss). Nevertheless, in patients submitted to reconstruction following Billroth I technique, these values were very low and no patient showed severe steatorrhea. These results are quite understandable, since in Billroth I there is transit through the duodenum ${ }^{19,36}$. Such results were also achieved experimentally, in rats submitted to gastrectomy and different reconstructive techniques ${ }^{2,24}$. Adequate fat absorption after gastrectomy depends fundamentally on how fat reaches the small bowel. Fat emulsification and esterification is significantly lower in rats submitted to gastrectomy than in controls, and malabsorption after gastrectomy occurs not only because of intraluminal disorder in emulsification and micelles formation, but also because of deficiency of lipase and other enzymes ${ }^{29}$. The postgastrectomy syndrome can generate all of these disturbances ${ }^{8}$. When the Rosanov technique was described in detail, technical simplicity was the main argument, as an anastomosis is easier and safer than closing a duodenal stump. Other advantages were also described: there is always enough mesentery, without compromising vascularization of bowel loop; and there is no risk of nervous or vascular transection, such as happens on jejunal transposition. These advantages can be achieved in almost all patients, regardless of size, fat distribution and morphology. The first of the few published studies describing this technique shows also that the patients were fed in a progressive and fractioned way, without any notable digestive disorder, particularly diarrhea ${ }^{17}$. The modification proposed in this study is the absence of external ligation of jejunal loop. It is well known that external intestinal ligations - as proposed by Rosanov ${ }^{17}$, Tomoda and others, including those who performed duodenal ligation in pyloric exclusion surgery have a tendency to slowly and progressively come to the lumen of the bowel, and to be eliminated after that, while there is recanalization of that bowel and intestinal transit passes through again ${ }^{2,13,14,32}$. That is why we believe that if the surgery is performed without this ligation, the results should be similar, allowing food to go through two paths, avoiding fat malabsorption after total gastrectomy. The only presented technique that did not produce the habitual levels of steatorrhea nor alkaline esophagitis after total gastrectomy, was easy to perform, without heightening the risks of the surgery, was the 
one described by Moricca and modified by Paletto ${ }^{30}$, which is physiologically similar to modified Rosanov. Unfortunately, there is no study that shows its advantages over any other technique. Therefore, decades after the first descriptions of the advantages of a duodenum-preserving technique, there is not any published paper that can prove them with statistically reliable data. Steatocrit is a semi-quantitative method to detect steatorrhea in many clinical situations in which there is a deficiency in digestion, absorption or transportation of fat ${ }^{16}$. It represents the final expression of all forms of fecal fat excretion. It is as safe as the fecal fat determination method of Kamer, Bokkel-Huinink and Weyrs ${ }^{21}$ and Sudam III, with high specificity and sensibility ${ }^{10,16,25}$. Still, it is cheaper and easier to be executed, as it is not necessary to prescribe any specific, long-term diet nor to collect a large amount of feces. It has been shown that fecal acidification with perchloric acid can lead to a better result; this method became known as acid steatocrit and has better acceptance in the diagnosis and clinical follow-up of steatorrhea ${ }^{21,34,37}$. The group $\mathrm{C}$ animals had $4.15 \%$ of mean fecal fat and $66.67 \%$ had values equal to zero, while group $\mathrm{Y}$ had $28.18 \%$ as mean fecal fat and the lowest value was $11.11 \%$. The high statistic difference between groups $\mathrm{R}$ and $\mathrm{Y}$ steatocrit values $(p=0.0001)$ and similarity between $R$ and $C$, obtained in this study was enough to demonstrate that steatorrhea occurred more frequently in group $\mathrm{Y}$, corroborating existing literature that shows the value of duodenal transit in mixing food to bile, stimulation of pancreatic and biliary secretions and mechanical clearing of duodenal bacteria. As the three groups had the same diet, surgical technique (antiseptic technique, abdominal manipulation, bowel loop length and anastomotic technique), pre and post-operative conditioning, the only variable suitable for statistical analysis was the reconstructive technique: whether the food passed or not through the duodenum. And it was possible to demonstrate how fat absorption was difficult when duodenal transit does not occur.

This study used the Roux-en-Y as the parameter of comparison to the modified Rosanov technique, as it is the most used reconstructive technique after total gastrectomy worldwide ${ }^{5,24,26}$. We showed, as we already supposed based on previous knowledge of the literature, that duodenumpreserving reconstructive techniques, specifically the modified Rosanov technique, showed lower malabsorption and steatorrhea. The control group (group C) was created to eliminate biases that could be caused by the diet, and also to obtain reference values of steatocrit in the studied animals. Time of follow-up was short in this study, but no other experimental study was carried out for a longer period in this type of surgery. However, preserving duodenal transit had only advantages described in the literature: better mixing of food to enzymes; avoidance of bacterial overgrowth; increased intestinal transit time, lower occurrence of dumping syndrome; preservation of hormonal stimuli to pancreas; and use of all the possible absorptive bowel surface. It is a technique that can be used after total gastrectomy for body, fundus and antral malignancies, but it is not too much to remember that it is not prudent in malignancies of the antrum that invade the duodenum.

\section{Conclusions}

The evaluation of fat absorption in rats through the analysis of steatocrit values after total gastrectomy, comparing the techniques of Roux-en- $\mathrm{Y}$ and modified Rosanov for intestinal transit reconstruction, allows the following conclusion: total gastrectomy reconstructed with modified Rosanov technique showed similar steatorrhea as in the control group, while Roux-en-Y technique showed significantly higher steatorrhea than the control and modified Rosanov groups.

\section{References}

1. Adams JF. The clinical and metabolic consequences of total gastrectomy. 3. Notes on metabolic functions, deficiency states, changes in intestinal histology, and radiology. Scan J Gastroenterol. 1968; 3(2): 152-9.

2. Aires Neto T, Cavalcante JF, Brandão-Neto J, Araújo Filho I, Almeida MG, Rezende AA, Egito EST, Azevedo IM, Pinheiro LAM, Medeiros VB, Medeiros AC. Total gastrectomy with substitution of stomach by jejunal pouch with and without duodenal passage: study in rats. Acta Cir Bras. 2005; 20(suppl.1): 107-12.

3. Armbrecht U, Lundell L, Lindstedt G, Stockbruegger RW. Causes of malabsorption after total gastrectomy with Rouxen-Y reconstruction. Acta Chir Scand. 1988; 154 (1): 37-41.

4. Audibert L, Serra JA, Ribera JM. Previous history of gastrectomy in the aged: a mal nutrition with malignant aspect. Rev Clin Esp. 1992; 190 (3): 120-4.

5. Bae J, Park J, Yang H, Kim J. Nutritional status of gastric cancer patients after total gastrectomy. World J Surg. 1998; 22, 254-61.

6. Bradley EL 3d, Isaacs JT, Mazo JD, Hersh T, Chey WY. Pathophysiology and significance of malabsorption after Roux-en-Y reconstruction. Surgery. 1977; 81 (6): 684-91.

7. Bradley El, Isaacs J. Postresectional anemia: a preventable complication of total gastrectomy. Arch Surg. 1976, 111 (8), 844-8.

8. Coelho-Neto JS, Andreollo NA, Lopes LR, Nishimura NF, Brandalise NA, Leonardi LS. Late follow-up of gastrectomized patients for peptic ulcer: clinical, endoscopic and histopathological aspects. Arq Gastroenterol. 2005;42(3):146-52.

9. Cristallo M, Braga M, Agape D, Primignani M, Zuliani W, Vecchi M, Murone M, Sironi M, Di Carlo V, Di Franchis R. Nutritional status, function of the small intestine and jejunal morphology after total gastrectomy for carcinoma of the stomach. Surg Gynecol Obstet. 1986; 163 (3): 225-30.

10. Csendes A, Smok G, Burdiles P, Antezana C, Espíndola M, Espíndola L, Csendes P. Intestinal malabsorption in patients treated with total gastrectomy. Rev Med Chil. 1993, 121 (12): 1416-21.

11. Díez-Cascón A, Díez-Cascón Menéndes E. Conceptos fisiopatológicos referentes a los pacientes sometidos a gastrectomía total. Rev Esp Enf Ap Digest 1989, 76 (6): 595-600.

12. Eagon JC, Miedema BW, Kelly KA. Postgastrectomy syndromes. Surg Clin NAm. 1992; 72 (2): 445-65.

13. Fujiwara Y, Kusonoki M, Nakagawa K, Tanaka T, Yamamura T, Utsonomiya J. Scintigraphic assessment of double tract reconstruction after total gastrectomy. Dig Surg. 1998, 15 (5): 404-9. 
14. Gainant A, Cubertafond $\mathrm{P}$, Vire O. Influence de la remise en circuit du duodénum aprés gastrectomie totale chez le rat. J Chir. 1985, 122 (4): 265-7.

15. Garofalo A, Santoro E. Double circuit esophagojejunoduodenal plasty in reconstruction of the alimentary tract after total gastrectomy. Surg Gynecol Obstet. 1985, 161 (6): 581-4.

16. Guarino A, Tarallo L, Greco L, Cesarano L, Guandalini S, Rubino A. Reference values of steatocrit and its modifications in diarrheal diseases. Gastroenterology. 1989; 96, 421-7.

17. Hepp J, Pernod R. Conservation du transit duodenal après gastrectomie par interposition jejunale. Le procédé de Rosanov. Presse Med. 1958; 29: 65-6.

18. Holstein CS Von. Long-term prognosis after partial gastrectomy for gastroduodenal ulcer. World J Surg. 2000; 24, 307-14.

19. Holstein CS Von, Walther B, Ibrahimbegovic E, Akesson B. Nutritional status after total and partial gastrectomy with Roux-en-Y reconstruction. Br J Surg. 1991; 78 (9):1084-7.

20. Iivonen MK, Ahola TO, Matikainen MJ. Bacterial overgrowth, intestinal transit, and nutrition after total gastrectomy: comparison of a jejunal pouch with Roux-en $\mathrm{Y}$ reconstruction in a prospective random study. Scand $\mathbf{J}$ Gastroenterol. 1998; 33, 63-70.

21. Kamer JH Van De; Bokkel-Huinink H, Weyrs HA. Rapid method for the determination of fat in feces. J Biol Chem. 1949; 177:244-355.

22. Lawrence Jr. W, Vanamee P, Peterson AS, Mcneer G, Levin $\mathrm{S}$, Randall HT. Alterations in fat and nitrogen metabolism after total and subtotal gastrectomy. Surg Gynecol Obstet. 1960;23:123-8.

23. Leth RD, Abrahamsson H, Kilander A, Lundell LR. Malabsorption of fat after partial gastric resection: a study of pathophysiologic mechanisms. Eur J Surg. 1991; 157 (3): 205-8.

24. Li Destri G, Trombatore G, La Greca G, Rinzivillo C, Rodolico M, Desiderio C, Orsina N, Di Cataldo A, Puleo S. Total gastrectomy: nutritional status after different reconstruction techniques: an experimental study. J Surg Oncol. 1992; 49 (2): 98-102.

25. Maranhão HS, Wehba J. Esteatócrito e Sudan III na pesquisa de esteatorréia em crianças: comparação com o método de Van de Kamer. Arq Gastroenterol. 1995; 32 (3): $140-5$.
26. Miani S, Sgroi S, Bianchi E, Ghilardi G, Longhi F, Scorza R. Critical evaluation of the reconstruction of the intestinal continuity after total gastrectomy by the Moricca technique. Minerva Chir. 1996; 51 (7-8):519-25.

27. Moricca F. Reconstruction du tube digestif après gastrectomie totale: observation et résultats sur 27 patients opérés par un procédé personnel. J Chir. 1983; 120 (5): 299-301.

28. Moricca F, Pandolfo G. La nutrizione post-operatoria del gastrectomizzato. Chir Gastroenterol. 1979; 13: 506.

29. Ohtsu S, Mori K, Misumi A, Akagi M. Mechanisms of fat malassimilation following total gastrectomy in rats. Gastroentrol Jpn. 1983, 18(1): 1-10.

30. Paletto AE, Gaetini A, Nano M, Mossetti C, Boltri F, Dei Poli M. La doppia ricanalizzazione esofagodigiunoduodenale ed esofagodigiunale dopo gastrectomia totale. Minerva Chir. 1981;36: 1285-9.

31. Ribeiro AF. Esvaziamento gástrico de líquidos em ratos submetidos à ligadura do ducto biliar [Tese - Doutorado]. Campinas: Faculdade de Ciências Médicas da Universidade Estadual de Campinas; 1999.

32. Safatle NF. Bolsa duodenojejunal antiperistáltica na reconstrução do trânsito digestivo após gastrectomia subtotal e na síndrome pós-gastrectomia: técnica. Arq Gastroenterol. São Paulo. 1984, 21(2): 59-67.

33. Sategna-Guidetti C, Bianco L. Malnutrition and malabsorption after total gastrectomy: a pathophysiologic approach. J Clin Gastroenterol. 1989; 11(5): 518-24.

34. Schwartz A, Beger HG. Gastric substitute after total gastrectomy: clinical relevance for reconstruction techniques. Langenbecks Arch Surg. 1998; 383 (6): 485-91.

35. Silva RCMA. Esteatorréia pós-gastrectomia. Relação com tipo de cirurgia e possibilidades de tratamento clínico [Tese - Doutorado]. Campinas: Faculdade de Ciências Médicas da Universidade Estadual de Campinas; 1991.

36. Tovey FI, Godfrey JE, Lewin MR. A gastrectomy population: 25-30 years on. Postgrad Med J. 1990; 66 (776): 450-6.

37. Tran M, Forget P, Van Den Neucker A, Strik J, Van Kreel B, Kuijten R. The acid steatocrit: a much improved method. J Pediatr Gastroenterol Nutr. 1994; 19; 299-303.

38. Van Outryve M, Huybrechts W, Blaauw AM, De Weerdt GA, Beke R, Barbier F. Jejunal bile salts and microflora in patients with partial gastrectomy. Am J Gastroenterol. 1978; 69(5):550-8.

\section{Correspondence:}

Gustavo Sevá-Pereira

Av. Andrade Neves, 707

13013-161 Campinas - SP Brazil

Phone/Fax: (55 19)3236-0128

gustavo@progastro.med.br
Conflict of interest: none Financial source: none

Received: July 05, 2006

Review: August 13, 2006 Accepted: September 18, 2006

\section{How to cite this article:}

Sevá-Pereira G, Lopes LR, Brandalise NA, Andreollo NA. Fat absorption after total gastrectomy in rats submitted to Rouxen-Y or Rosanov-like double-transit technique. Acta Cir Bras. [serial on the Internet] 2006 Nov-Dec;21(6). Available from URL: http://www.scielo.br/acb. 